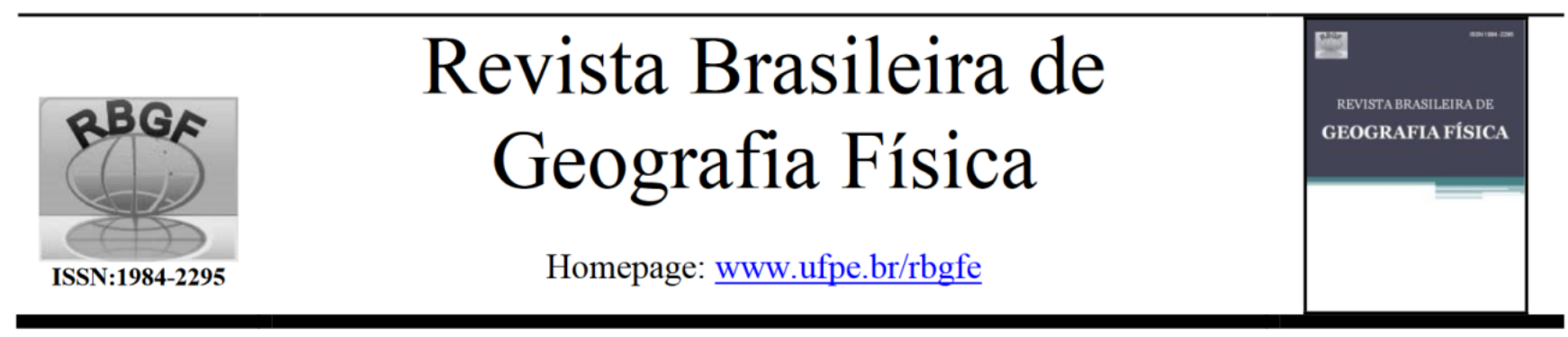

\title{
Geomorfologia Estrutural e Relações Morfodinâmicas da Bacia do Ribeirão Vovozinha, Faxinal-PR
}

\author{
Eder Borges ${ }^{1}$, Edison Fortes ${ }^{2}$
}

${ }^{1}$ Mestrando do Programa de Pós-graduação em Geografia da Universidade Estadual de Maringá, Av. Colombo, 5790 Zona 7, CEP 87020-900, Maringá-PR. e-mail: ederunderlineborges@ hotmail.com (autor correspondente); ${ }^{2}$ Professor Doutor do Programa de Pós-graduação em Geografia da Universidade Estadual de Maringá, Av. Colombo, 5790 Zona 7, CEP 87020-900, Maringá-PR. e-mail: edison-fortes @ hotmail.com

Artigo recebido em 18/09/2017 e aceito em 14/12/2018

\section{R E S U M O}

Este artigo tem por finalidade compreender os controles erosivos exercidos por diferentes níveis de base, representados por diques de diabásio, na bacia hidrográfica do Ribeirão Vovozinha, localizada dentro dos limites municipais de Faxinal, PR. Constatou-se, através de campanhas de campo na área de estudo, segmentos geomorfológicos altimetricamente desnivelados, atribuídos à erosão diferencial por parte da rede de drenagem, submetida a tais influências estruturais. A região faz parte da Serra Geral e está inserida na borda da Bacia Sedimentar do Paraná, no contexto da divisa entre o Terceiro e o Segundo Planaltos Paranaenses. Afloram na área de estudo, da base para o topo, os arenitos, os siltitos e os argilitos da Formação Rio do Rasto, os arenitos das formações Botucatu e Piramboia e os basaltos da Formação Serra Geral. A partir da análise integrada de dados geológicos e geomorfológicos foram propostos quatro domínios geomorfológicos para a área de estudo: o Domínio das Superfícies Dissecadas e Escarpadas (DSDE), o Domínio das Superfícies Sedimentares Intermediárias (DSSI), o Domínio das Superfícies Estruturais Ígneas Intrusivas (DSEII) e o Domínio das Superfícies Sedimentares Depressionárias (DSSD). O DSDE e o DSSI correspondem a uma superfície situada a montante da bacia. O DSSD representa uma superfície a jusante. O desnivelamento altimétrico, entre os segmentos geomorfológicos citados, é resultado da atuação diferencial de processos erosivos fluviais, nos terços superior e inferior da bacia, submetida ao controle estrutural exercido por um dique de diabásio, integrado ao DSEII.

Palavras chave: Bordas planálticas. Ribeirão Vovozinha. Faxinal-PR. Mapeamento geomorfológico.

\section{Structural Geomorphology and Morphodynamic Relations of the Ribeirão Vovozinha Basin, Faxinal-PR}

\begin{abstract}
A B S T R A C T
The purpose of this article is to understand the erosive controls exerted by different base levels, represented by diabase dikes, in the Ribeirão Vovozinha basin, located within the municipal boundaries of Faxinal, PR. It was verified, through field campaigns, altimetrically uneven geomorphological segments, attributed to the drainage network differential erosion, subjected to such structural influences. The region is part of the Serra Geral and is inserted at the Paraná Sedimentary Basin border in the context between the Third and Second Plateau in Paraná state. The sandstones, siltstones and argillites of the Rio do Rasto Formation, the sandstones of the Botucatu and Piramboia formations and the basalts of the Serra Geral Formation appear in the study area, from the base to the top. Based on the geological and geomorphological data integrated analysis, four geomorphological domains were proposed for the study area: the Dissected and Steep Surfaces (DSDE) domain, the Intermediate Sedimentary Surfaces (DSSI) domain, the Intrusive Igneous Structural Surfaces (DSEII) domain and the Sedimentary Depression Surfaces (DSSD) domain. The DSDE and DSSI domains correspond to an area located upstream of the basin. The DSSD domain represents a downstream surface. The altimetric unevenness between the mentioned geomorphological segments is a result of the fluvial erosive processes differential performance at the upper and lower thirds of the basin, submitted to the structural control exerted by a diabase dyke, integrated to the DSEII domain.
\end{abstract}

Keywords: Plateau edges. Vovozinha stream. Faxinal-PR. Geomorphological mapping. 


\section{Introdução}

A plataforma brasileira, cuja origem está atrelada a ciclos orogênicos do Pré-cambriano (4,5 b.a. - 570 m.a), constitui a base estrutural da Bacia Sedimentar do Paraná. A história evolutiva da referida bacia ocorreu no Fanerozoico (570 m.a.- atual), em etapas que envolveram eventos de natureza tectônica, sedimentar e magmática (Almeida, 1967).

De acordo com Maack,1968, o estado do Paraná está inserido em duas grandes unidades geotectônicas: Escudo Atlântico, onde afloram rochas do Pré-cambriano e bacia sedimentar do Paraná (rochas sedimentares e vulcânicas da bacia sedimentar do Paraná, provenientes do Éon Fanerozoico, Eras Paleozoica, Mesozoica e Cenozoica), essas últimas mergulham em direção oeste, rumo à calha do rio Paraná.

Em linhas gerais, Maack,1968, define o relevo do estado do Paraná em cinco grandes compartimentos ou regiões de paisagens naturais: o Litoral, a Serra do Mar, o Primeiro Planalto ou Planalto de Curitiba, o Segundo Planalto ou Planalto de Ponta Grossa, e o Terceiro Planalto ou Planalto de Trapp do Paraná ou de Guarapuava. A topografia do estado do Paraná é composta por planaltos que inclinam suavemente para oeste, rumo ao centro da bacia sedimentar do Paraná, formando uma sequência de patamares concordantes com os estratos litológicos. Essas estruturas apresentam, em suas bordas, degraus estruturais que se apresentam como escarpas de estratos litológicos, que chegam a conter desníveis de até $200 \mathrm{~m}$, gerando um enorme contraste topográfico com as superfícies do Segundo Planalto Paranaense, onde o relevo exibe formas dissecadas pela rede de drenagem em rochas mais friáveis. Essas bordas planálticas foram soerguidas por processos epirogenéticos no Terciário (65 m.a. - 1,6 m.a.) e imprimem na paisagem feições típicas de relevos de cuestas formados por capas de sedimentos, com fronts voltados para leste.

As bordas paranaenses da Bacia Sedimentar do Paraná são compostas, mais a leste, pela Escarpa Devoniana, sustentada por sedimentos devonianos (limite entre Primeiro e Segundo Planaltos Paranaenses) e pelo segundo grande degrau de escarpa de cuestas que marca a transição entre a sequência paleozoica e as formações geológicas do Mesozoico (Escarpa Triássico-Jurássica, limite entre o Terceiro e o Segundo Planaltos Paranaenses) (Maack, 1968). A área de estudo está situada na Escarpa TriássicoJurássica, limite entre o Terceiro e o Segundo Planaltos Paranaenses.
As rochas que constituem a Bacia Sedimentar do Paraná datam do Éon Fanerozoico. A sequência sedimentar paleozoica, na bacia, estende-se pelo Segundo Planalto desde a Escarpa Devoniana (Serra de São Luiz de Purunã, divisa do Primeiro com o Segundo Planaltos Paranaenses), até a Escarpa da Serra Geral (divisa do Segundo com o Terceiro Planaltos Paranaenses), a transição entre esses dois grandes compartimentos de relevo define, geologicamente, o limite entre as formações geológicas do Paleozoico e Mesozoico. O período Devoniano (410 m.a. - 355 m.a.) marca o princípio da era Paleozoica na Bacia Sedimentar do Paraná (Thomaz, 1984). Afloram na área de estudo, as formações Rio do Rasto (Permiano Superior, 270 m.a. -250 m.a.), Piramboia e Botucatu (Triássico e Jurássico, 250 m.a. - 205 m.) e Serra Geral (Juro-Cretáceo).

No decorrer do século XX, trabalhos precursores realizados por De Martonne, 1943; King, 1956; Ab'Sáber, 1962, 1969, 1970; Bigarella et al.1965 e Bigarella e Mousinho (1965), atribuíram a evolução do relevo de extensas áreas do continente sul-americano e brasileiro (inclusive o estado do Paraná), às flutuações climáticas do Cenozoico (65 m.a. - atual). Conforme essa ótica, a gênese das superfícies erosivas, cujos remanescentes persistem na paisagem local, decorre de alternâncias episódicas entre climas áridos a úmidos, ocorridos no período que compreende o final da era mesozoica (250 m.a. - 65 m.a.) e a cenozoica.

Bigarella et al. 1965, assim como Bigarella e Andrade, 1965, reconheceram a superfície mais antiga do Terceiro Planalto Paranaense, (Cretáceo superior-Terciário inferior) designando-a como Pd3, identificada no reverso das escarpas da Serra Geral, em planaltos fragmentados, seccionados pela rede de drenagem. Os remanescentes desse nível de aplainamento são detectados em topos da Serra do Cadeado, em altitudes que ultrapassam $1.000 \mathrm{~m}$, limitados por escarpas e cuestas constituídas por basaltos da Formação Serra Geral e arenitos da Formação Botucatu. Essa superfície corresponde à Superfície Sul-Americana de King, 1956.

Situada em níveis topográficos inferiores, com idade atribuída ao Terciário médio, ocorre a superfície $\mathrm{Pd}$ 2, formada a partir do retrabalhamento da superfície Pd3 (Bigarella et al., 1965; Bigarella e Andrade, 1965). No contexto regional das bordas planálticas da Bacia Sedimentar do Paraná, esse nível de aplanamento é reconhecido em segmentos de escarpas e relevos residuais, formando patamares e ombreiras.

Elaborada a partir do retrabalhamento da superfície Pd2, a superfície de aplanamento Pd1 
corresponde a um nível mais baixo e recente (Terciário superior-Quaternário inferior) que os níveis supracitados (Bigarella et al., 1965; Bigarella e Andrade, 1965). Esse nível erosivo caracteriza-se por depressões embutidas nos vales ligeiramente inclinadas para jusante. Na contextualização regional da área de estudo, essa superfície corresponde a zonas deprimidas, recobertas parcialmente por materiais detríticos, relacionadas a setores de acumulação, com altitudes em torno de $500 \mathrm{~m}$.

Pretende-se através da realização desse estudo, compreender os controles erosivos exercidos, por diferentes níveis de base, representados por diques de diabásio, na bacia hidrográfica do Ribeirão
Vovozinha, localizada dentro dos limites municipais de Faxinal, região centro-norte do Paraná, entre as coordenadas geográficas $24^{\circ} 5^{\prime} 20^{\prime \prime}$ e $24^{\circ} 7^{\prime} 10^{\prime \prime}$ de latitude sul, e $51^{\circ} 20^{\prime} 20^{\prime \prime}$ e $51^{\circ} 22^{\prime} 30^{\prime}$ " de longitude oeste (figura 01). Para tal intento, realizou-se um mapeamento geomorfológico, em escala de detalhe (1:25.000), evidenciando formas e feições associadas à morfodinâmica local. No decorrer desta pesquisa constatou-se, diante das dimensões reduzidas da bacia estudada $\left(10,48 \mathrm{~km}^{2}\right)$, a necessidade de contextualizar os atributos geológicos e geomorfológicos de maneira mais abrangente, de forma a estabelecer correlações do relevo da bacia com o contexto geomorfológico do entorno.

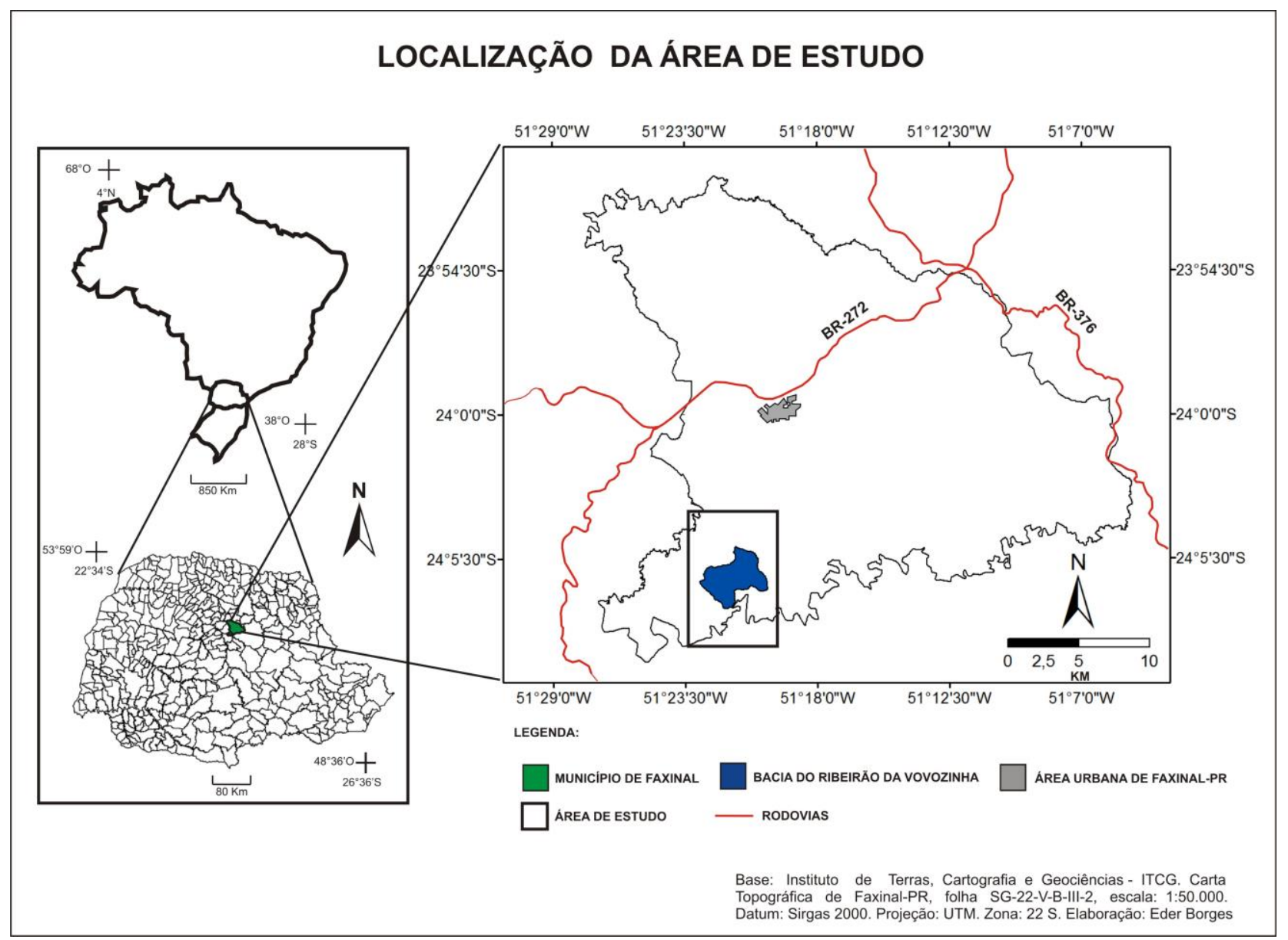

Figura 1: Localização da Bacia do Ribeirão Vovozinha, Faxinal-PR. Fonte: Do autor 
A partir do mapa geomorfológico foram investigados os controles geomorfológicos exercidos por diferentes níveis de base, representados por diques de diabásio, os quais geraram superfícies altimetricamente desniveladas, em áreas a montante $\mathrm{e}$ a jusante da referida bacia hidrográfica, segmentadas pelas intrusões de diabásio.

A pertinência deste estudo justifica-se pela possibilidade de se correlacionar o fator estrutural, a Geomorfologia e a rede de drenagem, atuando de forma integrada na evolução da paisagem. $\mathrm{Na}$ área alvo da pesquisa, por se tratar de um contexto de borda de bacia sedimentar, com contatos litológicos diversos e relevo dissecado, o fator estrutural é um elemento chave.

\section{Material e métodos}

Os procedimentos metodológicos adotados nesta pesquisa envolveram a digitalização da carta topográfica de Faxinal (folha SG-22-V-B-III-1; escala 1:50.000) fornecida pelo Instituto de Terras, Cartografia e Geociências (2015). As variáveis de análise extraídas desse material foram inseridas como banco de dados em ambientes SIG's (Sistemas de Informação Geográfica), onde foram manipulados os mapas temáticos pertinentes à pesquisa.

Com o auxílio de dados SRTM - Shuttle Radar Topography Mission (imagens aéreas com dados topográficos, obtidas por sensores radar) com resolução de 30 m, disponíveis no Projeto Topodata (Valeriano, 2005), foram extraídas as curvas de nível, a partir das quais foram produzidos os mapas de declividade e hipsometria no software Arc Gis ${ }^{\circledR}$ (versão 10). O projeto Topodata consistiu em interpolar as imagens SRTM para aumentar sua resolução de 90 para $30 \mathrm{~m}$.

As informações referentes à rede de drenagem, unidades litológicas (arcabouço litoestratigráfico / depósitos quaternários) e Geomorfologia (formas e feições associadas ao relevo) foram extraídas de fotografias aéreas, na escala 1:25.000, fornecidas pelo Instituto de Terras e Colonização do Norte do Paraná - ITC-PR, por meio do método de fotointerpretação visual de fotografias aéreas, descrito pelo Manual Técnico de Geomorfologia, IBGE, 2009. Os dados obtidos a partir dessas imagens foram analisados por um estereoscópio de bolso, georreferenciados e incorporados ao banco de dados no software Arc Gis® (versão 10).

No mapa geomorfológico foram delimitados domínios geomorfológicos, definidos como um arranjo regional de formas semelhantes, resultantes de uma morfogênese comum. Foram demarcadas, a partir da fotointerpretação de fotografias aéreas, as formas e feições de relevo, considerando tanto o contexto genético, quanto os padrões de formas IBGE, 2009. O critério para delimitação dos domínios geomorfológicos considerou, além da associação de formas, as similaridades quanto aos padrões de altimetria e declividade.

\section{Resultados e discussão}

São identificados na área de estudo dois modelados principais de relevo: o de dissecação e o de acumulação. Situado no contexto de transição entre o Segundo e o Terceiro Planaltos Paranaenses, o modelado de dissecação está localizado no extremo nordeste do recorte da área de estudo, condiz a escarpas erosivas e escarpas adaptadas de falha com fronts marcando desníveis altimétricos acima dos $100 \mathrm{~m}$, onde afloram os arenitos de idade mesozoica das formações Piramboia e Botucatu, essas escarpas demarcam o limite entre o modelado de dissecação e o de acumulação.

Sobrepostas aos arenitos das formações Piramboia e Botucatu, assentam-se as rochas da formação Serra Geral. Os basaltos da formação Serra Geral predominam no reverso das escarpas da Serra Geral, no Terceiro Planalto Paranaense, onde constituem estruturas que inclinam suavemente para noroeste e oeste, rumo à calha do rio Paraná, em conformidade às demais camadas estratigráficas da bacia do rio homônimo. No reverso das escarpas, a pedogênese gera solos autóctones e espessos, devido à intensa alteração supérgena sobre os basaltos, predomina o latossolo vermelho, distrófico típico, álico, com textura argilosa.

Situam-se no modelado de dissecação as maiores declividades (acima dos 25\%), (figura 03), e as maiores elevações topográficas, que coincidem com feições de elevações residuais e escarpas, sustentadas por litologias resistentes à erosão (formações Serra Geral e Botucatu), onde as cotas altimétricas atingem $825 \mathrm{~m}$ (figura 02 ).

$\mathrm{O}$ modelado de acumulação equivale às áreas deprimidas e dissecadas, caracterizadas pela acumulação de sedimentos. Conforme exposto na figura 03, no modelado de acumulação, são identificadas as menores classes de declividade (abaixo de $15 \%$ ) e as menores altitudes, onde as cotas altimétricas variam de 400 a $520 \mathrm{~m}$ (figura 02). Nessas áreas, os solos predominantes são o neossolo litólico e argissolo vermelho-amarelo, com espessuras que variam de poucos $\mathrm{cm}$ até cerca de $2 \mathrm{~m}$, a pedogênese ocorre tanto sobre a litologia Rio do Rasto, quanto em coberturas superficiais transportadas pela ação da gravidade e depositadas em médias e baixas vertentes.

Sotoposta às formações geológicas, anteriormente mencionadas, a Formação Rio do Rasto, 
mais antiga da sequência estratigráfica na região do município de Faxinal (Paleozoico), constitui a base litológica da maior parte da área de estudo e também de grande extensão do Segundo Planalto Paranaense, onde é recoberta parcialmente por depósitos de idade quaternária. A fraca resistência aos processos erosivos dessa unidade litológica, composta por arenitos e siltitos, em comparação às rochas sobrepostas na coluna estratigráfica, confere à paisagem feições de relevo rebaixadas, com predomínio de colinas convexas. $\mathrm{O}$ contato estratigráfico entre a
Formação Rio do Rasto e as formações mesozoicas é marcado por discordância erosiva.

Observa-se, na figura 04, que a área abordada pelo estudo é caracterizada por complexos de rampas de colúvio e leques aluviais, onde se nota que o material de origem provém de locais elevados onde predominam modelados de dissecação. Esses materiais são transportados pelos rios e pela ação da gravidade, acumulando-se nas bases das escarpas e junto aos fundos de vale.

MAPA HIPSOMÉTRICO DA ÁREA DE ESTUDO

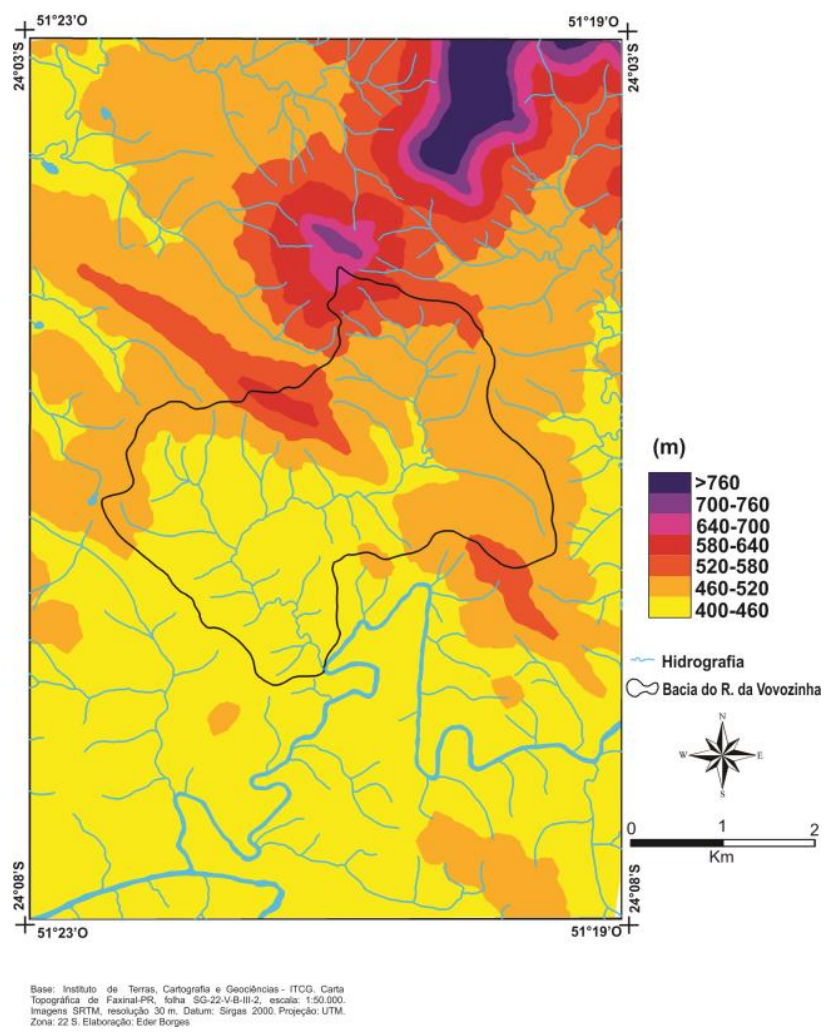

Figura 2: Mapa hipsométrico da região do Ribeirão Vovozinha, Faxinal-PR 


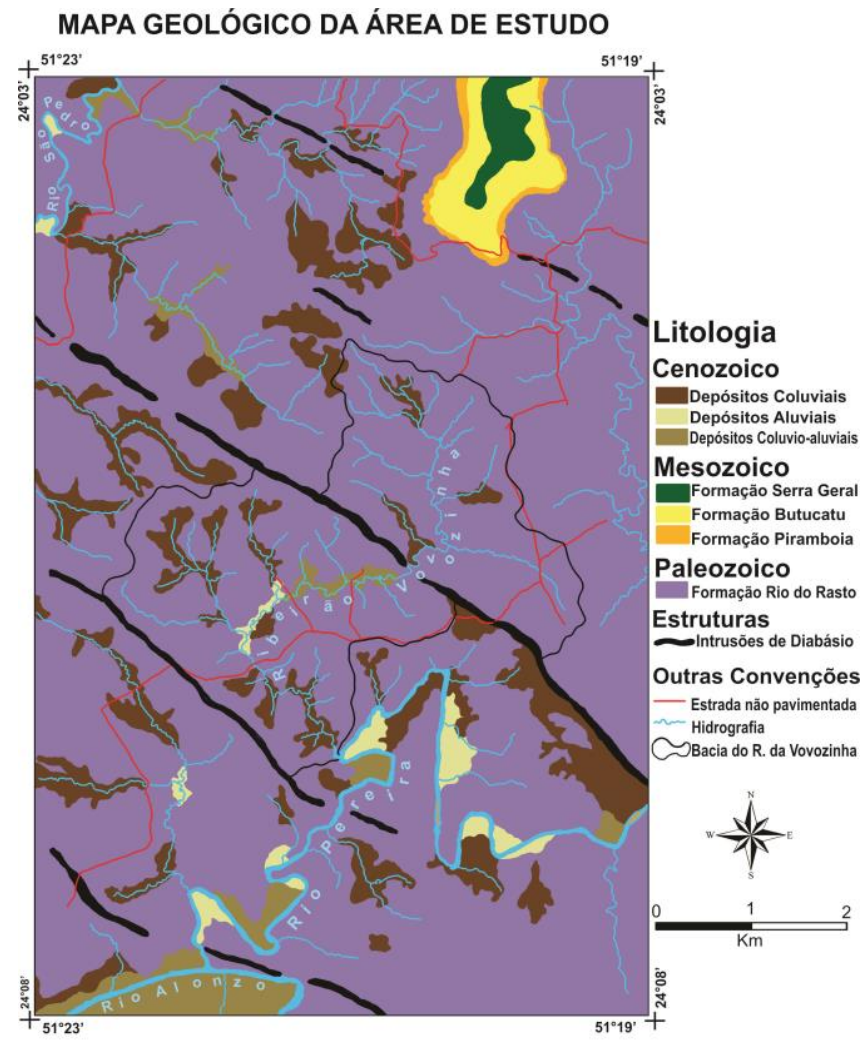

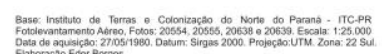

Figura 4: Mapa geológico da região do Ribeirão Vovozinha, Faxinal-PR

MAPA DE DECLIVIDADE DA ÁREA DE ESTUDO

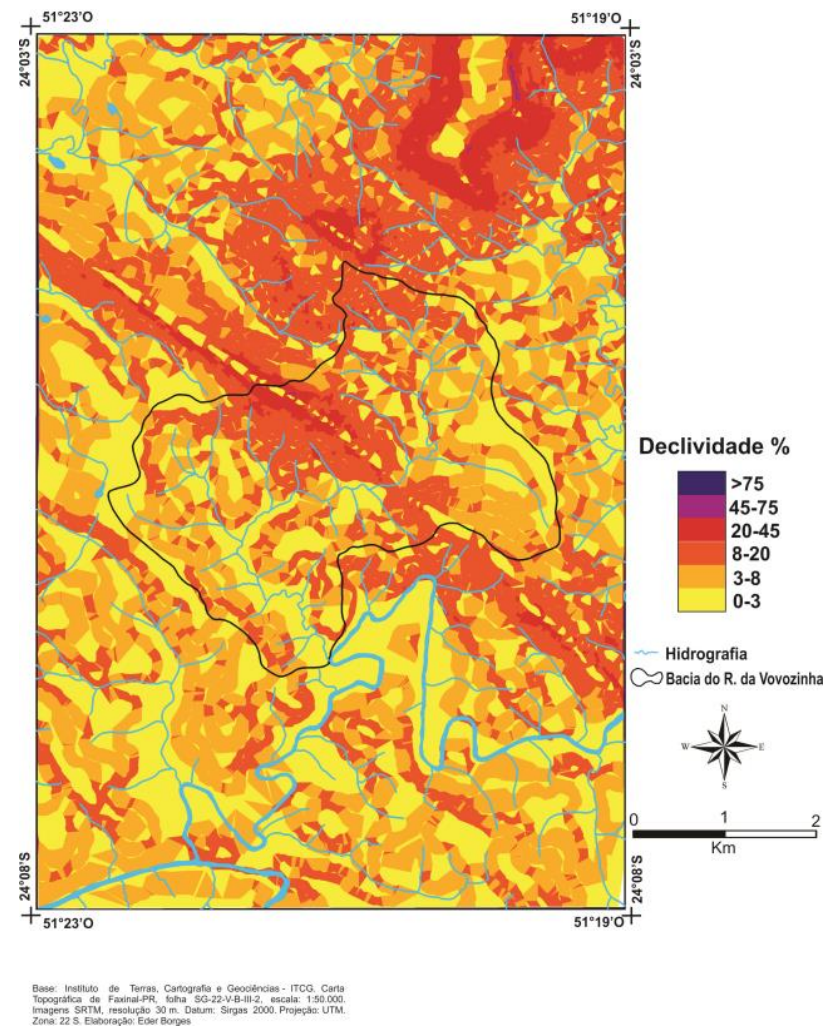

Figura 3: Mapa de declividade da região do Ribeirão Vovozinha, Faxinal-PR

Os depósitos coluviais distribuem-se ao longo das baixadas sedimentares, acumulando-se em médias e baixas vertentes. É comum a presença nesses depósitos, de detritos das formações Serra 
Geral e Botucatu, com espessuras que variam de poucos $\mathrm{cm}$ até mais de $2 \mathrm{~m}$, relacionados a eventos de solifluxão, denotando ambientes com distintos estágios de energia, atuando nos processos erosivos e deposicionais.

Afloramentos de depósitos compostos por detritos de basaltos da Formação Serra Geral e arenitos da Formação Botucatu, encontrados em área que compreende as nascentes do Ribeirão Vovozinha, indicam remanescentes de paleociclos morfogenéticos, contudo, demandam de análise quanto à constituição granulométrica e relação com os ciclos erosivos (Figura 05).

Situados na fácie inferior, os cascalhos brechosos, suportados com pouca ou nenhuma matriz, facetados e pouco retrabalhados, típicos de fluxo torrencial de transporte em curta distância, indicam erosão mecânica e um fluxo torrencial de transporte. $\mathrm{Na}$ parte superior, o material coluvial de matriz argilosa, dotado de notável diminuição da granulometria para o topo, demostra um paleoambiente com considerável diminuição de energia dos agentes erosivos e deposicionais, gerando um fluxo mais lento, típico de climas úmidos, similares aos atuais.

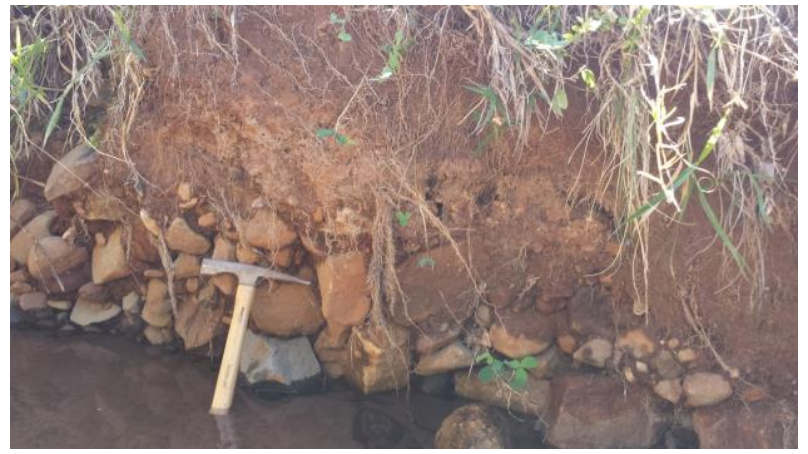

Figura 3: Depósito coluvial descrito em local que abriga as nascentes do Ribeirão Vovozinha.

$\mathrm{Na}$ área de estudo, os depósitos aluviais ocorrem restritamente confinados às planícies aluviais dos rios Pereira, São Pedro e baixo curso do Ribeirão Vovozinha, associados a barras de canais e depósitos de inundação. São formados por blocos e cascalhos arredondados e subarredondados e diques marginais arenosos.

Os depósitos colúvio-aluviais indiferenciados são os menos presentes, ocorrendo em fundos de vale, no médio curso do Ribeirão Vovozinha e confinados em curvas do rio Pereira.

Feições diversas como escarpas íngremes, degraus estruturais e relevos residuais são reflexos de uma considerável complexidade geológica e geomorfológica, atributos inerentes a essa região.

As escarpas de caráter erosivo e estrutural, sustentadas por rochas mesozoicas presentes à nordeste da área de estudo, são feições expressivas, que guardam resquícios de ciclos morfogenéticos ocorridos no Terciário, determinantes para a atual configuração do relevo. A história cenozoica de evolução do relevo, marcada pela atuação de paleoclimas e da Neotectônica é atestada pelos depósitos sedimentares que recobrem partes das superfícies do modelado de acumulação. Essas últimas contrastam com as escarpas, conferindo à paisagem um aspecto mais constante e suave, Fortes et al., 2008.

Através do critério de mapeamento geomorfológico, estabelecido pelo IBGE, 2009, que agrupa conjunto de formas com gênese comum, a área de estudo foi compartimentada em quatro unidades: Domínio das Superfícies Dissecadas e Escarpadas (DSDE), Domínio das Superfícies Sedimentares Intermediárias (DSSI), Domínio das Superfícies Estruturais Ígneas Intrusivas (DSEII), e Domínio das Superfícies Sedimentares Depressionárias (DSSD) (Figura 06). Esses domínios possuem feições associadas à morfodinâmica local.

O domínio DSDE está situado à nordeste da área de estudo e compreendido entre as altitudes de 520 e $820 \mathrm{~m}$. Esse domínio concentra feições de escarpas em conformidade com as formações geológicas mesozoicas, demarcando uma descontinuidade do Terceiro Planalto Paranaense, a qual estaria relacionada, segundo Manieri, 2010 e Santos 2010, à retomada erosiva em processos de recuo paralelo de encostas, devido a flutuações climáticas durante o Quaternário. Com cerca de $130 \mathrm{~m}$ de amplitude, essas escarpas são as feições mais marcantes e pronunciadas da área investigada. Nelas, e unicamente nesse domínio, afloram todas as litologias presentes na sequência estratigráfica da região do Ribeirão Vovozinha e registram-se também os maiores valores de declividade (de 25 a mais de $75 \%$ ), atestados pelo acentuado escarpamento, mostrados nas figuras 03 e 06.

Os arenitos de idade mesozoica, das formações Piramboia e Botucatu, afloram entre as altitudes de 650 e $720 \mathrm{~m}$ (figuras 02 e 04). Os arenitos 
finos e friáveis da Formação Piramboia ocorrem espacialmente de forma fragmentada e limitada e encontram-se parcialmente erodidos, formando reentrâncias nas escarpas. $\mathrm{O}$ arenito Botucatu, de caráter mais resistente, forma ressaltos contíguos nas encostas. Esses arenitos sustentam os patamares e escarpas mencionados anteriormente.

Em sobreposição, (figura 04), assentam-se os basaltos da Formação Serra Geral, essas rochas afloram nas áreas mais elevadas à nordeste, a cerca de $750 \mathrm{~m}$ de altitude, em topos da escarpa mesozoica. Correspondem a basaltos pórfiros, dacitos, riodacitos e riolitos (Mineropar, 2001).

A densidade de drenagem é variável conforme os diferentes atributos geológicos e geomorfológicos, esses segmentos escarpados e de relevo dissecado abrigam também elevadas densidades de drenagem, onde há uma maior concentração de canais de primeira e segunda ordem e uma pronunciada ramificação da rede hidrográfica.

Na porção sudoeste desse domínio, há uma zona em que a drenagem expõe um padrão semirradial, esse padrão de drenagem está em conformidade com uma elevação residual, controlada por um dique de diabásio, presente no local, cujo topo alinhado em direção NW-SE atinge a cota de $730 \mathrm{~m}$, associados a essa feição de relevo há níveis de ombreiras em zonas de ruptura litológica. Esse elemento do relevo está representado na figura 06, pela simbologia de feição de topo. De acordo com Vargas et al. 2013 é comum a ocorrência de padrões de drenagem radiais e sub-radiais, em áreas que foram sujeitas a derrames e formaram soleiras de diabásio, onde a declividade e as estruturas dômicas se tornam fator controlador, exercendo influência sobre os padrões de drenagem.

Embora as escarpas adaptadas de falha sejam frequentes no contexto regional das escarpas da serra do Cadeado, há apenas uma única ocorrência na área de estudo: condiz a um pequeno trecho retilíneo no front da escarpa, à nordeste, de direção aproximada NW-SE, voltada para sudoeste, concordante às direções preferenciais dos diques de diabásio (figura 06). Nesse trecho, o recuo da escarpa cessou ao se deparar com a intrusão de diabásio, de caráter mais resistente. Configura-se, dessa forma, no local, uma escarpa adaptada de falha, a partir do direcionamento de um dique de diabásio. O prolongamento dessa escarpa assume a forma de uma escarpa erosiva, com formatos de "meia lua", formados pela erosão remontante.

Nessas zonas, que abrigam cabeceiras de drenagem, os canais de primeira e segunda ordem atuam junto aos fronts das escarpas, por meio da erosão remontante, processo que culmina no recuo dessas escarpas. Regularmente, essas nascentes desenvolvem feições de anfiteatros. A partir dessa zona de escarpas e de cabeceiras de drenagem, a rede hidrográfica flui para noroeste e sudeste. São comuns nas zonas escarpadas, pertencentes ao modelado de dissecação, a ocorrência de falhas normais e subverticais.

O domínio DSDE corresponde tanto ao modelado de dissecação quanto de acumulação, não se restringe às zonas escarpadas, mas abrange também áreas elevadas onde se verificam depósitos coluviais que acompanham o direcionamento de inclinação dos compartimentos e, portanto, da drenagem. Feições como escarpas erosivas, rupturas de declive, ombreiras e vales em "V" são frequentes em modelados de dissecação e estão atreladas a processos erosivos. As rupturas de declive, côncavas e convexas, estão associadas às escarpas e elevações residuais onde a descontinuidade no aclive decorre da erosão diferencial em locais de contato litológico.

Ao longo de vertentes abrutas, o domínio DSDE exibe diferentes níveis de ombreiras, difundidas entre 520 e $700 \mathrm{~m}$ de altitude. Esses ressaltos litológicos correspondem à erosão diferencial em zonas de contato entre diferentes formações litológicas, ou mesmo entre as diferentes fácies da Formação Rio do Rasto. Também devido a esses atributos, esse domínio manifesta uma série de rupturas de declive côncavas e convexas.

Os interflúvios planos são associados a feições escarpadas e de topo plano, sustentadas pela Formação Serra Geral, com declividades em torno de 3 a $8 \%$, localizas no extremo nordeste da área de estudo. No restante desse domínio e também nos demais prevalecem os interflúvios convexos secundários (que dividem canais de ordens inferiores) e interflúvios convexos principais (que delimitam canais de ordens superiores e bacias hidrográficas). Esses últimos, em alguns casos, coincidem com intrusões de diabásio.

O domínio DSSI reúne características distintas do domínio DSDE que é limítrofe ao domínio acima mencionado, cuja divisão é marcada principalmente por atributos altimétricos e de declividade. Possui relevo de traço monótono, com colinas convexas dissecadas e moldadas em arenitos e siltitos da Formação Rio do Rasto. As altitudes variam de 440 a $520 \mathrm{~m}$ aproximadamente (figura 02). As declividades oscilam de 3 a $15 \%$, as maiores declividades situam-se junto às elevações residuais, associadas a diques de diabásio, as menores declividades condizem ao aspecto colinoso do relevo (Figura 03). Ocorre o predomínio de vales em "V", es- 
cavados por uma rede de drenagem densa, com vários interflúvios convexos principais e secundários, atributos que corroboram o aspecto colinoso das vertentes. Ocorre o alargamento gradativo desses vales a jusante, rumo às áreas mais rebaixadas e dissecadas, gerando indício de que a morfodinâmica da região do Ribeirão Vovozinha ocorre de forma mais pronunciada nas áreas ao sul e sudoeste

Constata-se a presença de depósitos coluviais e, em menor quantidade, depósitos colúvio-aluviais e aluviais, esses últimos confinados nas planícies aluviais do rio São Pedro, no extremo no

O domínio DSEII está posicionado de forma intermediária, na porção central da área de es- tudo. Possui fisionomia estreita e alongada prolongando-se conforme a direção de um dique de diabásio, que forma através da erosão diferencial uma serra alongada, consoante a um significativo lineamento de direção NW-SE, conforme exposto na figura 06. Os enxames de diques de diabásio, presentes nas bordas planálticas, estão inseridos no contexto do Arco de Ponta Grossa, do qual o eixo principal coincide com a área de estudo. Os diques, orientados, predominantemente, conforme direção NW-SE, controlam estruturalmente a rede de drenagem atuando como feições de interflúvios convexos principais. Não raramente, esses diques são seccionados por falhas N-S e NE-SW, permitindo a transposição da rede de drenagem.

\section{MAPA GEOMORFOLÓGICO DA ÁREA DE ESTUDO}

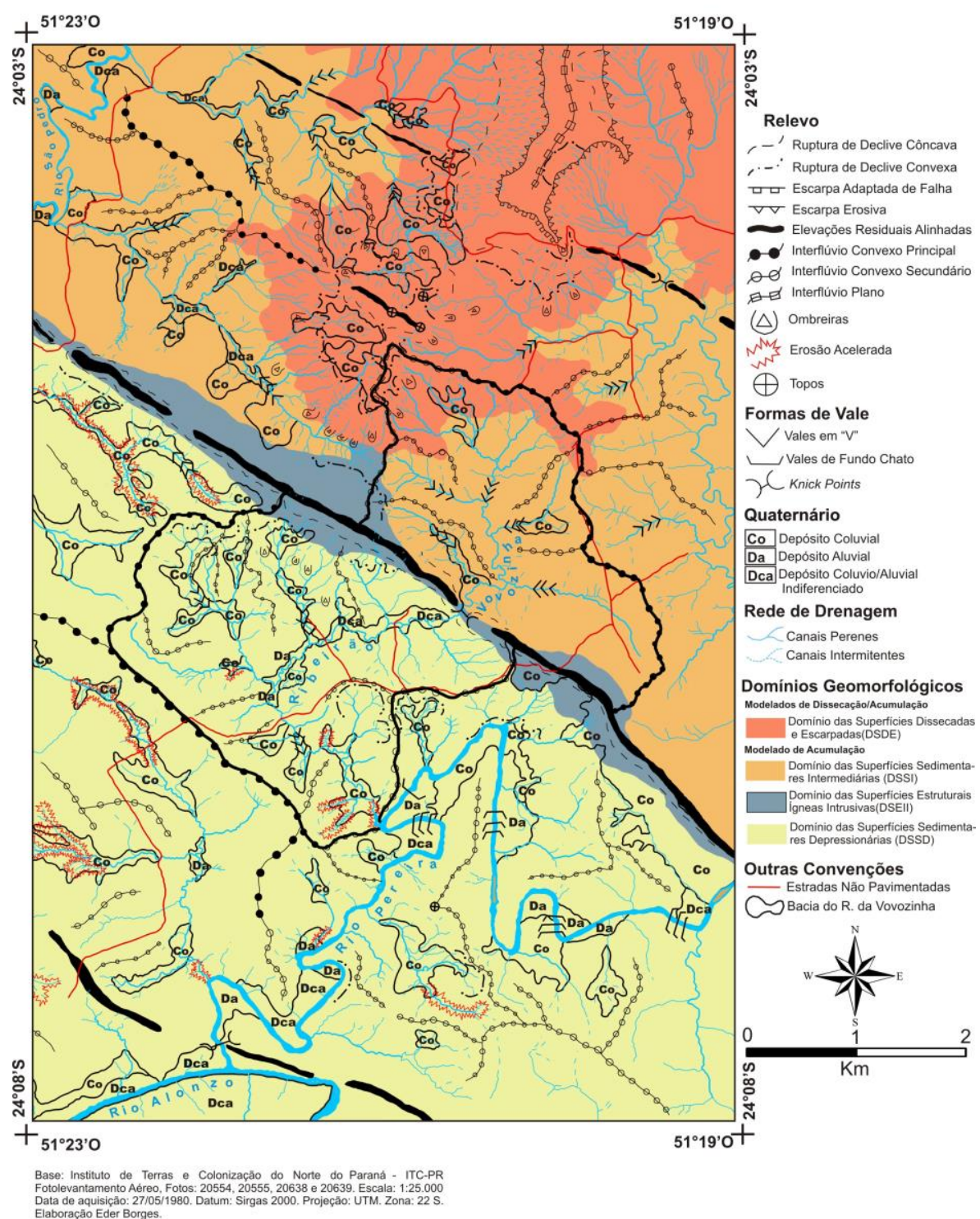

Figura 4: Mapa geomorfológico da região do Ribeirão Vovozinha, Faxinal-PR 
Existem depósitos coluviais de forma restrita, em formas de rampas de colúvio nos sopés do dique, à sudeste. A figura 07 exibe um afloramento situado junto às paredes do dique de diabásio, de $2,10 \mathrm{~m}$ de espessura. $\mathrm{O}$ afloramento expõe blocos alterados de até $30 \mathrm{~cm}$ de diâmetro. A base apresenta maior alteração com matriz argilosa entre blocos centimétricos.

Os blocos da parte mediana e do topo apresentam famílias de fraturas de direção N33E / $44^{\circ} \mathrm{SE}$.

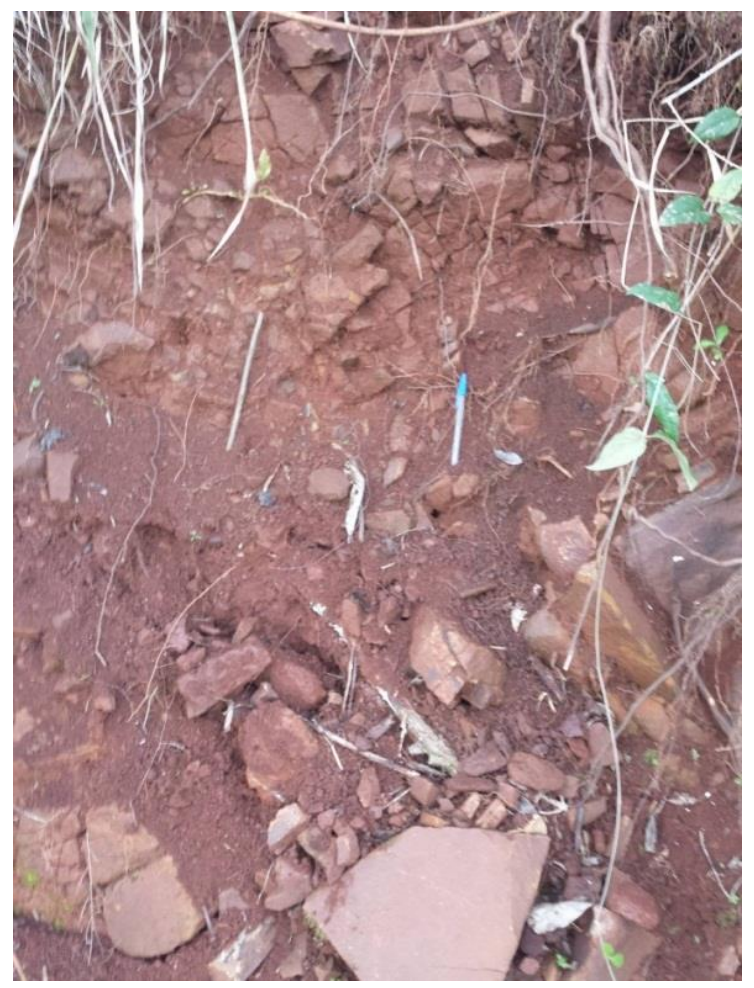

Figura 5: Afloramento de blocos angulosos alterados, localizado junto às paredes de dique de diabásio, domínio DSEII.

A drenagem possui um nível de base local, representado na figura 06 por um knick point. Nesse ponto, o dique de diabásio atua como barragem para o Ribeirão Vovozinha, reduzindo localmente a densidade e o desenvolvimento da drenagem.

As altitudes variam de $450 \mathrm{~m}$ na zona de knick point, a $620 \mathrm{~m}$ no topo do dique, as declividades variam de 8 a mais de $45 \%$, os valores mais elevados condizem a zonas de rupturas de declive côncavas em zonas de contato litológico e erosão diferencial, junto às paredes do dique.

Localizado na porção inferior da área de estudo, ao sul, e ocupando cerca de metade do recorte representativo dessa área, o domínio DSSD corresponde ao segmento geomorfológico mais baixo, dis- pondo de um relevo monótono, com os menores valores de declividade (3 a 15\%). Tratam-se de colinas suavemente onduladas, dissecadas e rebaixadas, esculturadas nas rochas da Formação Rio do Rasto. Assim como ocorre no domínio DSSI, essas feições de relevo contrastam com as escarpas, elevações residuais e serras alongadas, verificadas nos domínios DSDE e DSEII.

Embora haja a presença de algumas ombreiras ao norte, próximo da zona limítrofe com o domínio DSEII, não há uma concentração forte de ombreiras nesse domínio, essas se agrupam de forma expressiva no domínio DSDE. Localmente, as ombreiras representam patamares descontínuos, ocasionados por erosão diferencial.

Os diques de diabásio não se manifestam de forma relevante nesse domínio, porém, extensos interflúvios convexos principais de direção NW-SE, um deles representando o interflúvio sudeste da bacia do Ribeirão Vovozinha, prenunciam hipoteticamente situações de diques de diabásio que foram arrasados pela erosão, dispondo-se atualmente na paisagem de forma rebaixada.

Outra similaridade ao domínio DSSI é a quantidade expressiva de interflúvios convexos principais e secundários, o que reflete um relevo colinoso.

A densidade de drenagem é ligeiramente mais baixa nas áreas mais deprimidas, relativas aos fundos de vale e calhas fluviais do rio Pereira. $\mathrm{O}$ rio Pereira evidencia forte sujeição ao controle estrutural, pois exibe em seu curso situações anômalas como trechos retilíneos, angulosos e curvas bruscas, seu nível de base comanda os processos erosivos desse domínio geomorfológico.

A atuação de um clima úmido e os solos com elevada porosidade favorecem a erosão intensa nos modelados de acumulação. As erosões aceleradas, agregadas aos canais de primeira e segunda ordem, retratam o processo de erosão remontante, ravinamentos e entalhamento do talvegue que culminam no recuo das vertentes. O predomínio dessas feições sobre os depósitos quaternários atesta a vulnerabilidade de formações superficiais inconsolidadas aos processos erosivos regidos pela drenagem.

$\mathrm{Na}$ parte sudeste desse domínio, junto à base inferior da encosta do dique de diabásio, há um depósito coluvial com cerca de $1.950 \mathrm{~m}$ de comprimento e $350 \mathrm{~m}$ de largura média, nota-se que essa extensa cobertura coluvial está presente apenas de um lado do dique de diabásio, voltada para o domínio DSSD, isso ocorre porque o domínio DSSD é mais baixo, declinando para o rio Pereira, cujo nível de base está numa situação topográfica inferior. 
A expressividade das feições erosivas e deposicionais atesta que o domínio DSSD combina localmente modelados de dissecação com formas de deposição.

A figura 08 exibe perfis topográficos longitudinais que cortam as áreas relativas aos modelados de dissecação e de acumulação, expondo modificações de altimetria, declividade, geologia e relevo, revelando o controle estrutural exercido tanto pelas intrusões de diabásio quanto em áreas de contato litológico. O perfil X-X' corta o relevo de norte para sul, cruzando os domínios DSDE, DSSI, DSEII e DSSD, o perfil Z-Z' segmenta o relevo de norte para sul, percorrendo os domínios DSDE, onde trunca todas as litologias ocorrentes na área de estudo, DSEII e DSSD. Nota-se a ocorrência de segmentos geomorfológicos altimetricamente perfilados em desnível, em um efeito de "escadaria". Devido às escalas dos perfis topográficos, as coberturas cenozoicas não puderam ser representadas, mas esses depósitos foram comprovados pelo método de fotointerpretação de imagens aéreas e em campanhas de campo.

A figura 09 retrata os domínios geomorfológicos e as principais feições de relevo na região do Ribeirão Vovozinha: A- vista E-W das baixadas sedimentares relativas ao domínio DSSD; B- rampa de colúvio situada nos domínios DSEII e DSSD, mergulhando para SW, rumo ao nível de base do rio Pereira; C- vista SE-NW do dique de diabásio descrito no domínio DSEII e; D- panorama dos domínios DSDE (D3), DSSI (D3), DSEII (D3) e DSSD (D2).

O fator estrutural exerce forte controle sobre a drenagem local, condicionando a evolução diferencial de segmentos geomorfológicos e anomalias pronunciadas no curso fluvial do Ribeirão Vovozinha.

As nascentes do Ribeirão Vovozinha estão situadas no Segundo Planalto Paranaense, próximas às escarpas da Serra Geral. O curso principal flui em direção NW-SE a montante, sobre os domínios DSDE e DSSI, quando converge bruscamente para a direção NE-SW, adaptando-se a um ambiente de falha. Em seu médio curso, intercepta o domínio DSEII. A jusante, dentro do domínio DSSD e sobre o controle de base do rio Pereira, o canal muda bruscamente seu curso para a direção NW-SE, onde conflui com o rio Pereira, a cerca de $410 \mathrm{~m}$ de altitude. Em termos de hierarquia fluvial, trata-se de um canal de quarta ordem. O curso do Ribeirão Vovozinha possui extensão total de $8,38 \mathrm{~km}$, e formato em "S". Esses padrões morfológicos configuram anomalias que refletem a importância do controle estrutural.
A hipsometria do canal, exibida pelo perfil longitudinal do curso principal, destaca que as nascentes estão situadas a cerca de $630 \mathrm{~m}$ de altitude, próximas a uma elevação residual, descrita no domínio DSDE, ao norte da bacia. A partir disso, as cotas altimétricas do canal decaem mais de $100 \mathrm{~m}$, em menos de $1.000 \mathrm{~m}$ de curso (Figura 10).

O Ribeirão Vovozinha flui sobre o modelado de acumulação em relevos colinosos com vertentes convexas, esculpidas sobre a Formação Rio do Rasto. A cerca de $3.300 \mathrm{~m}$, em estágio intermediário de curso fluvial, o nível de base regional ou perfil de equilíbrio é afetado estruturalmente por uma soleira de diabásio, gerando ruptura no padrão de declividade do canal. Essa anomalia de drenagem se correlaciona a uma zona de knick point (figuras 10 e 12).

O knick point atua como nível de base local para o Ribeirão Vovozinha, em seu médio curso, a cerca de $460 \mathrm{~m}$ de altitude. Nesse trecho, o Ribeirão Vovozinha intercepta, através de uma falha de direção NE-SW, um dique de diabásio de direção NWSE, configurando um duto de escoamento e transferência da rede de drenagem, em rochas mais resistentes, para a porção jusante da bacia. O dique é um morro alongado e retilíneo, com largura média de $150 \mathrm{~m}$, que secciona a bacia em sua porção intermediária.

O canal apresenta na zona de knick point largura entre 4 e $6 \mathrm{~m}$, leito irregular e pedregoso, com corredeiras em soleiras de aspecto escalonado (Figura 12).

As cotas altimétricas inferiores dispõem-se do médio curso até a confluência com o rio Pereira, a cerca de $410 \mathrm{~m}$ de altitude.

O nível Pd1 denominado por Bigarella et al. (1965); Bigarella e Andrade (1965), foi identificado na área de estudo, coincidindo com os interflúvios de tributários de ordens inferiores do Ribeirão Vovozinha, em altitudes de 400 a $520 \mathrm{~m}$, (Figuras 13 e 14) nos domínios DSSI e DSSD.

Trata-se de feições suavemente onduladas que inclinam suavemente para jusante, modeladas em rochas da Formação Rio do Rasto, recobertas parcialmente por materiais detríticos, representando zonas de acumulação. 


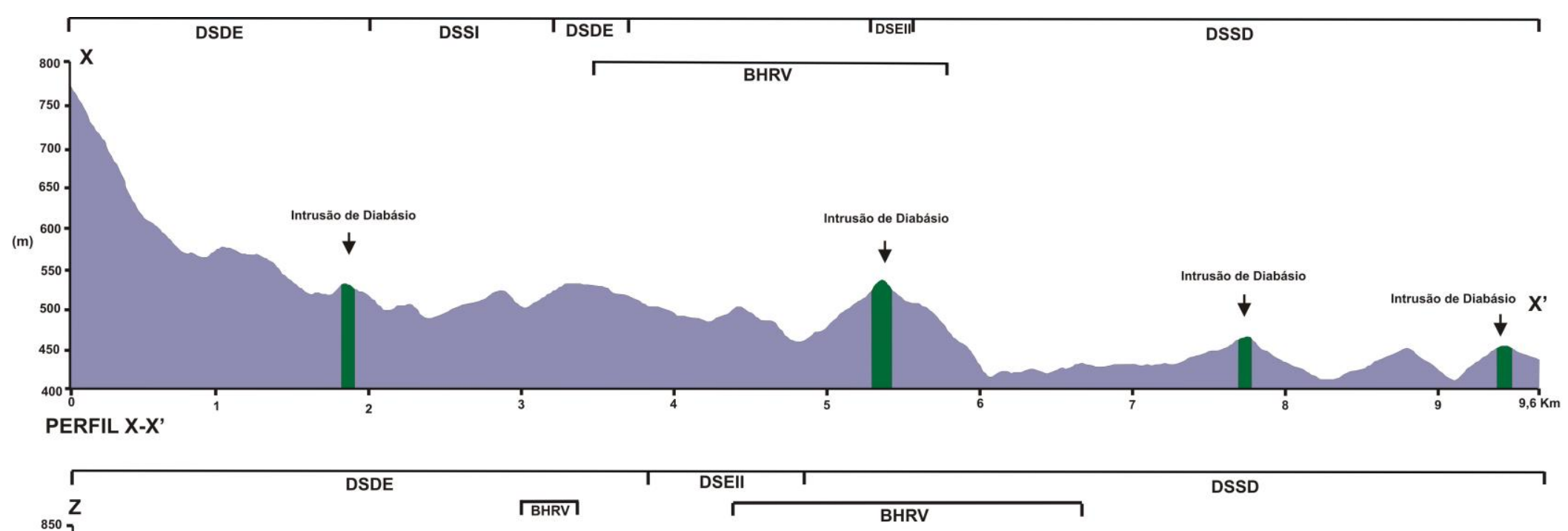

ESCALAS:

Escala vertical: $L_{0}^{50}$

Escala horizontal: ${ }_{0}^{\longrightarrow}, 5 \mathrm{~km}$

Exagero vertical: $5 \mathrm{x}$

GEOLOGIA:
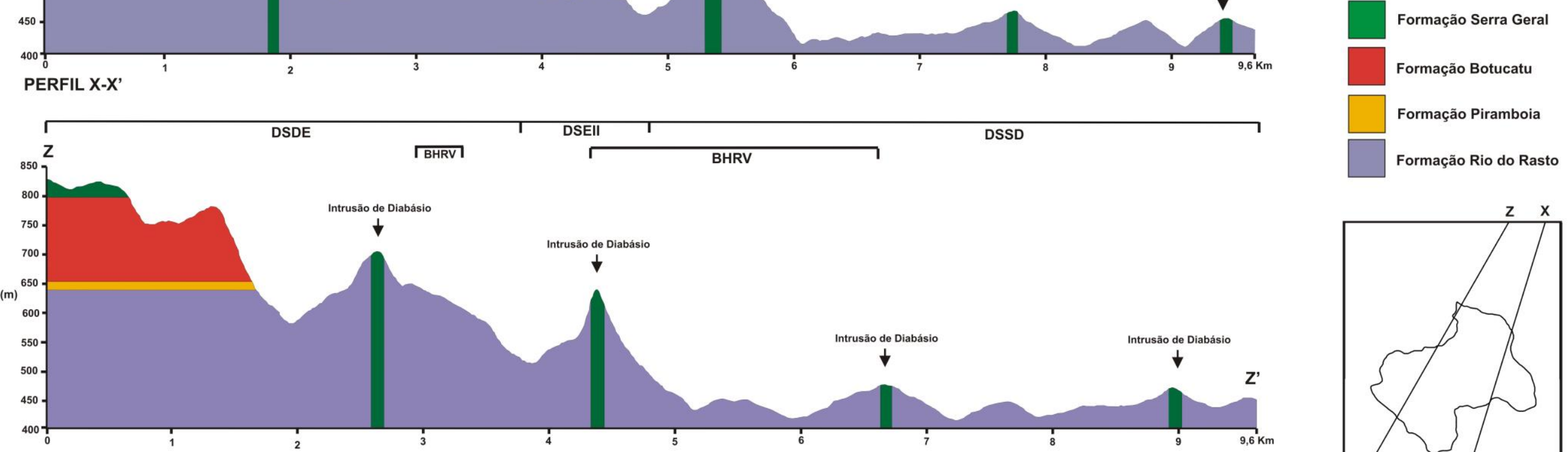

PERFIL Z-Z'

DSDE-Dominio das Superficies Dissecadas e Escarpadas

DSSI- Dominio das Superficies Sedimentares Intermediárias

DSEII- Dominio das Superficies Estruturais Igneas Intusivas

DSSD-Dominio das Superficies Sedimentares Depressionárias

BHRV-Bacia Hidrográfica do Ribeirão Vovozinha

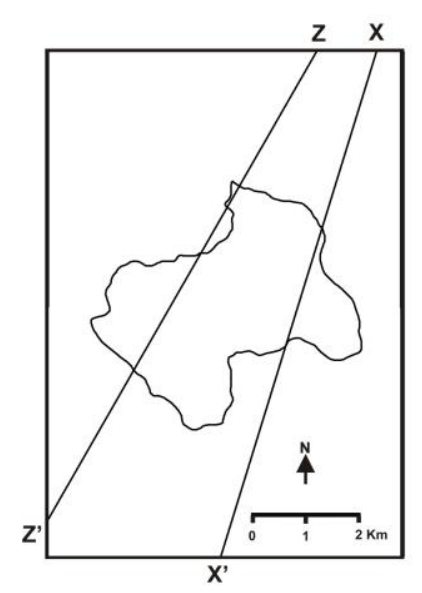

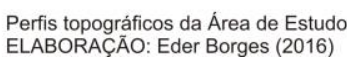

Figura 8: Perfis topográficos da região do Ribeirão Vovozinha, Faxinal-PR

Borges, E., Fortes, E. 

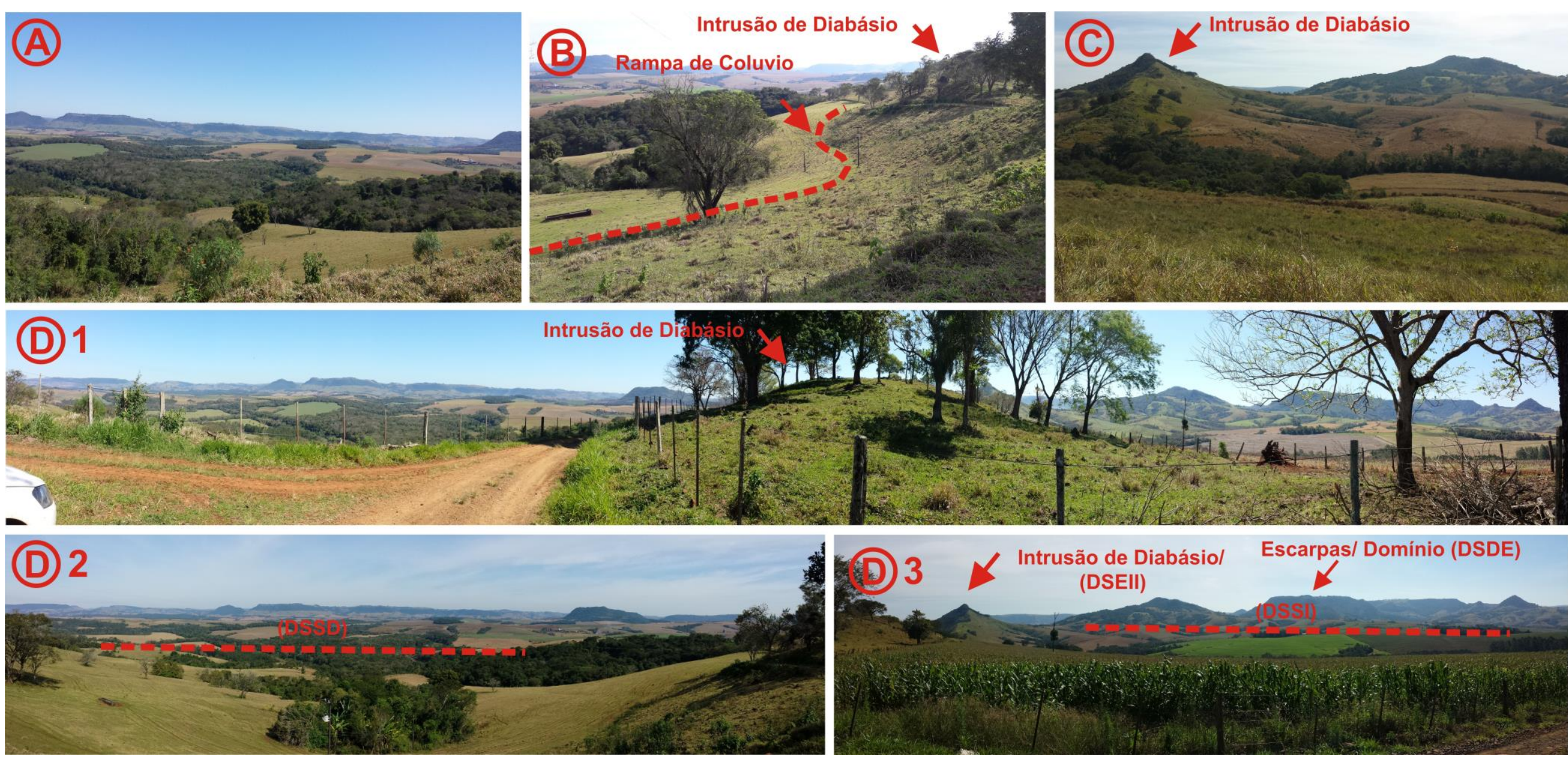

Figura 9: Domínios geomorfológicos e feições de relevo na região do Ribeirão Vovozinha, Faxinal-PR

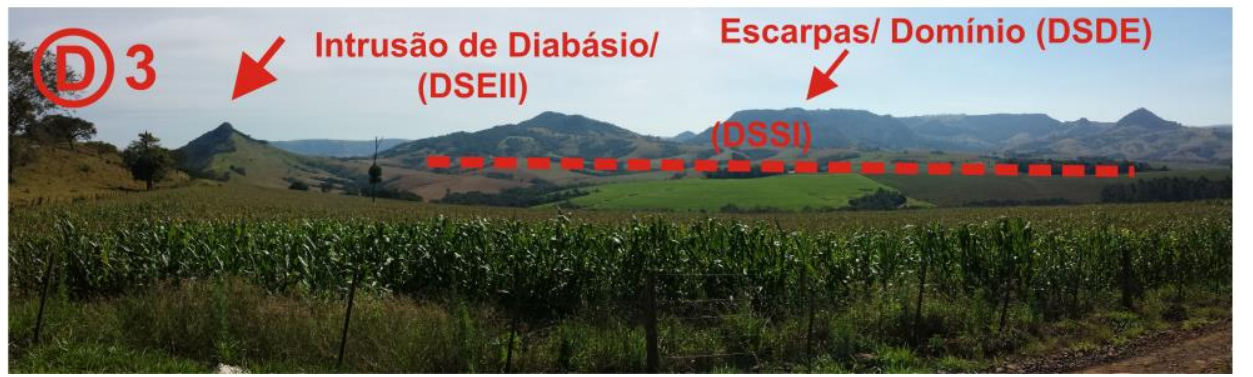




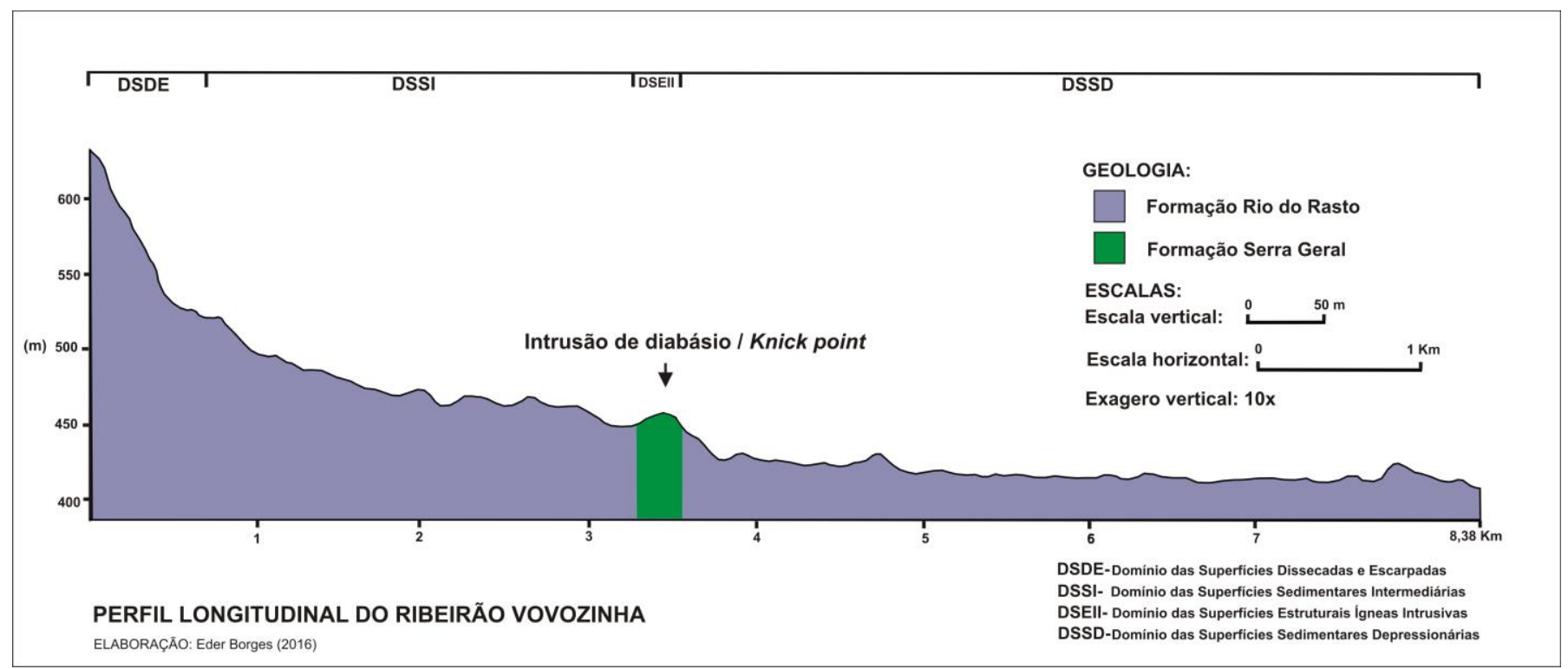

Figura 10: Perfil longitudinal do Ribeirão Vovozinha.

Há uma discordância altimétrica em torno de $60 \mathrm{~m}$, entre as superfícies Pd1 dispostas na parte montante da bacia, relativa ao domínio DSSI e jusante, relativa ao domínio DSSD (Figura 13).

O desnivelamento altimétrico entre essas superfícies é atribuído ao controle estrutural que o dique exerce, comportando-se como uma barreira, tanto para a drenagem local, quanto para os processos erosivos que atuam no desenvolvimento dessas superfícies. Esse lineamento estrutural exerce forte controle sobre a arquitetura da rede de drenagem e divide o relevo em segmentos geomorfológicos, altimetricamente, desnivelados.

O rebaixamento da superfície correspondente ao domínio DSSD é comandado pelo nível de base do rio Pereira, cuja planície aluvial situa-se entre 400 e 425 metros de altitude. No entanto, o nível de base do rio Pereira não exerce influência sobre os outros compartimentos de relevo, pois a intrusão de diabásio atua como barreira para a rede hidrográfica a montante.

Dessa forma, o nível de base local representado pelo dique de diabásio controla a erosão fluvial a montante, de forma que os processos de erosão e transporte de sedimentos, executados pela drenagem, tornam-se mais restritos no compartimento referente ao domínio DSSI, em comparação ao domínio DSSD, tornando a superfície disposta a montante da bacia, mais elevada. Isso ocorre porque toda a drenagem flui de forma confinada em um único canal.

A jusante, quando o canal ultrapassa a zona de knick point e adentra a zona submetida ao controle de base do rio Pereira, as declividades se tornam maiores, aumentando a vazão e os processos de dissecação.
Configura-se um quadro morfodinâmico local, onde no domínio DSDE predomina a erosão diferencial, comprovada através da presença de feições de escarpas erosivas, escarpas adaptadas de falha, ombreiras e rupturas de declive, formas associadas a contatos litológicos. Nos domínios DSSI, DSEII e DSSD predominam processos erosivos controlados por nível de base local.

Os depósitos Quaternários, provenientes dos modelados de dissecação distribuem-se pelas baixadas sedimentares, tornando-se feições recorrentes em todos os domínios geomorfológicos aqui propostos. No domínio DSSI a ausência de feições de erosão acelerada, associada a formas de relevo locais, indica processos erosivos mais restritos comparados ao domínio DSSD. As feições de erosão acelerada, presentes apenas no domínio DSSD, fornecem diagnósticos de que a superfície correspondente a esse domínio está sendo dissecada de forma mais intensa que as superfícies a montante, situadas em situações topográficas mais elevadas. Tais argumentos são reforçados pela presença de depósitos coluviais, aluviais e colúvio-aluviais, indiferenciados em maior número e extensões, no domínio DSSD.

Os domínios DSSI e DSSD, além de frações do domínio DSDE correspondem ao nível de aplainamento Pd1, designado por Bigarella et al. 1965 e Bigarella e Andrade 1965, submetidos a controles geomorfológicos, exercidos por diferentes níveis de base. Dessa forma, há a ocorrência de diferentes domínios geomorfológicos, onde o dique de diabásio, adjunto ao domínio DSEII, exerce uma influência forte nos processos de controle erosivo, tanto a montante como a jusante, gerando desnivelamento altimétrico na superfície Pd1. 
MAPA HIDROGRÁFICO DA ÁREA DE ESTUDO

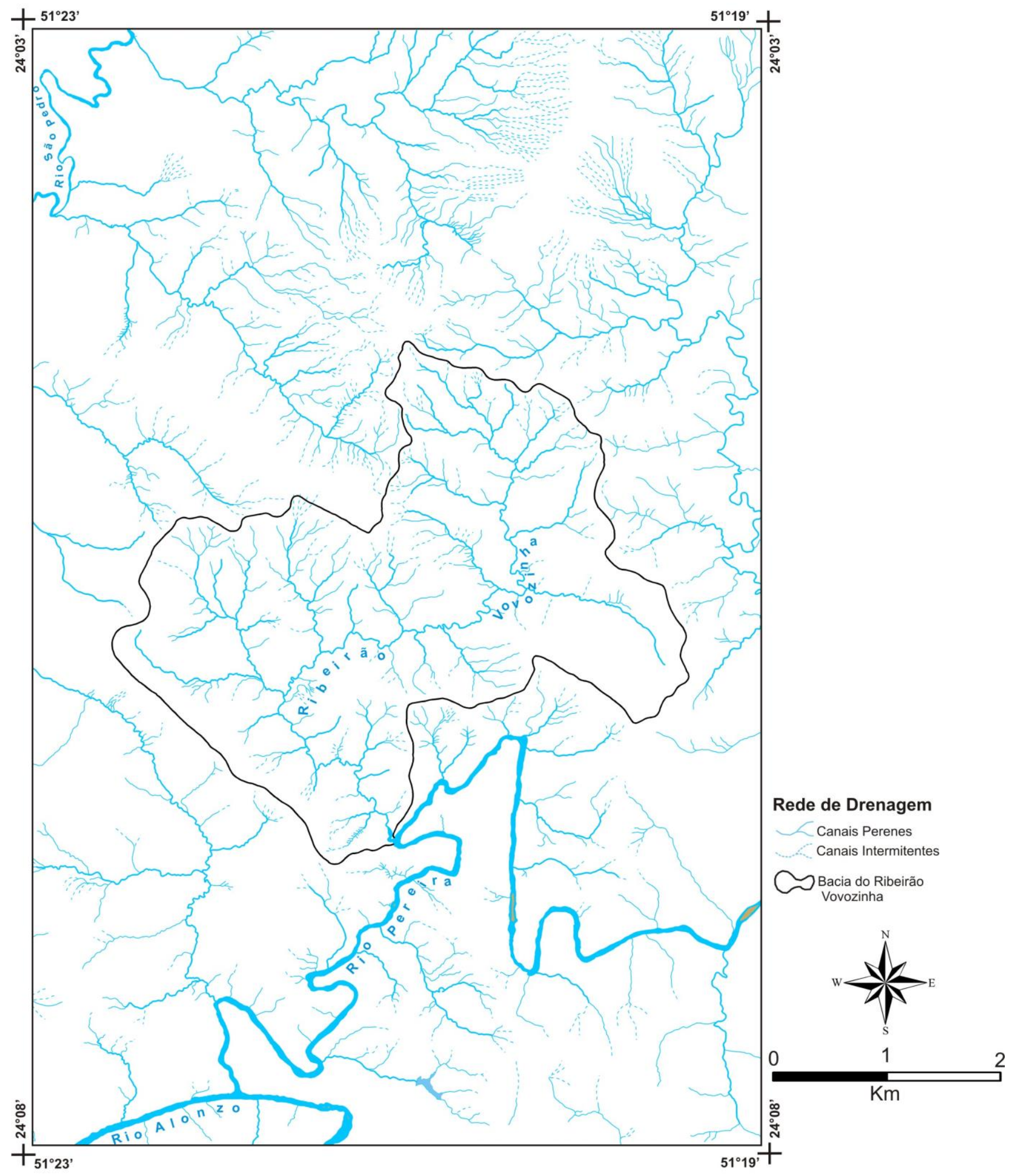

Base: Instituto de Terras e Colonização do Norte do Paraná - ITC-PR

Fotolevantamento Aéreo, Fotos: 20554, 20555, 20638 e 20639. Escala: 1:25.000

Data de aquisição: 27/05/1980. Datum: Sirgas 2000. Projeção: UTM. Zona: 22 S.

Elaboração Eder Borges

Figura 11: Mapa hidrográfico da região do Ribeirão Vovozinha, Faxinal-PR 


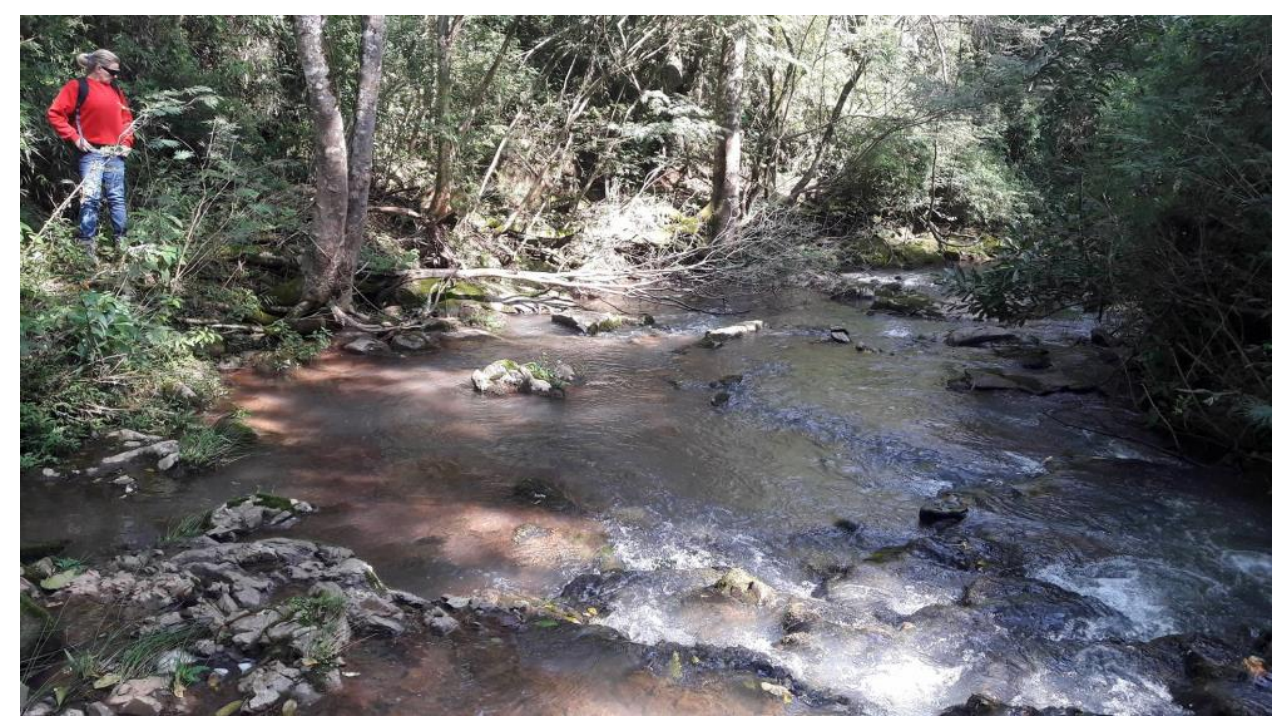

Figura 12: Ribeirão Vovozinha em seu médio curso, na zona de knick point

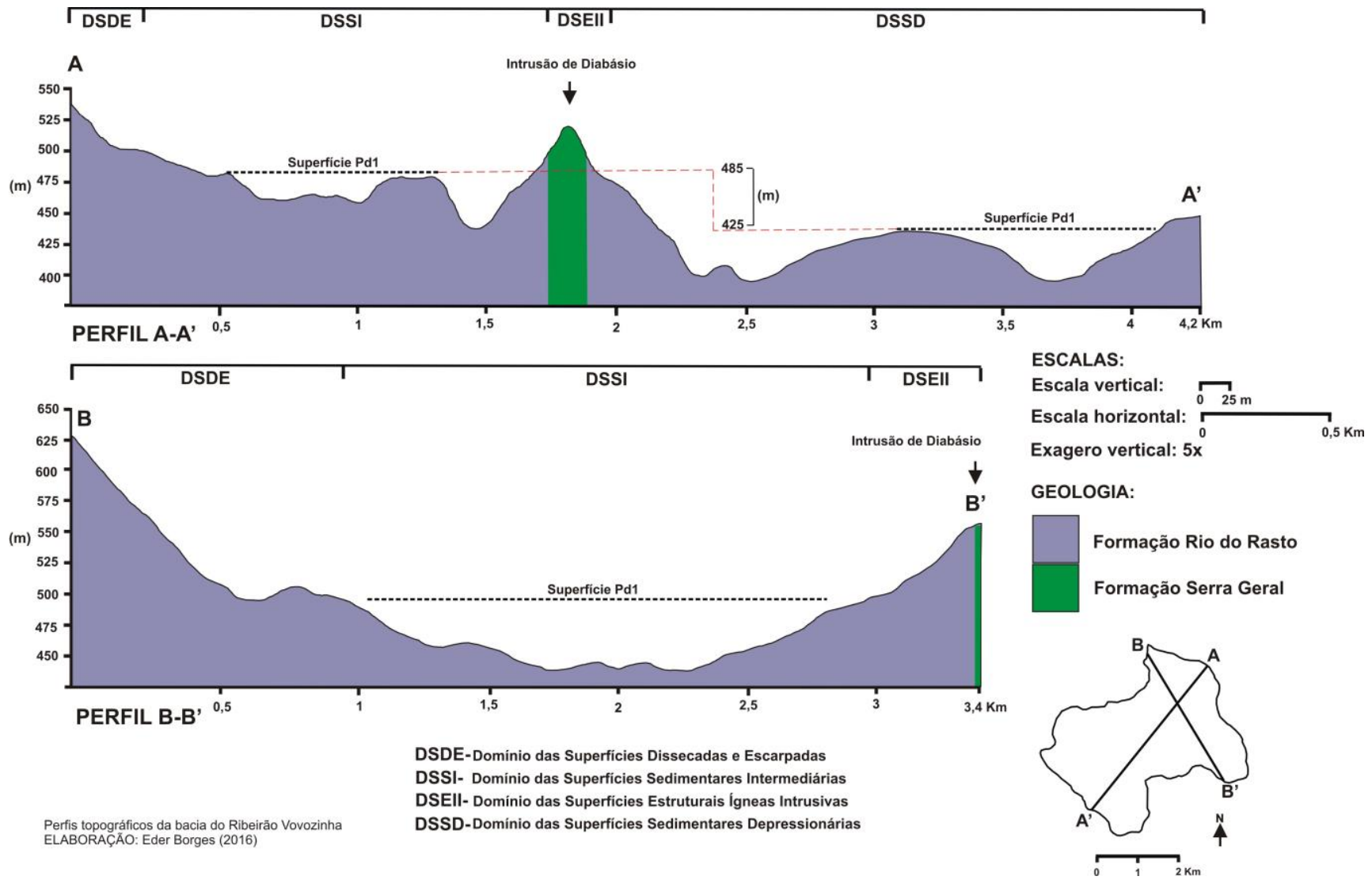

Figura:13 Perfis topográficos da bacia hidrográfica do Ribeirão Vovozinha, Faxinal, cortes A-A' e B-B' 


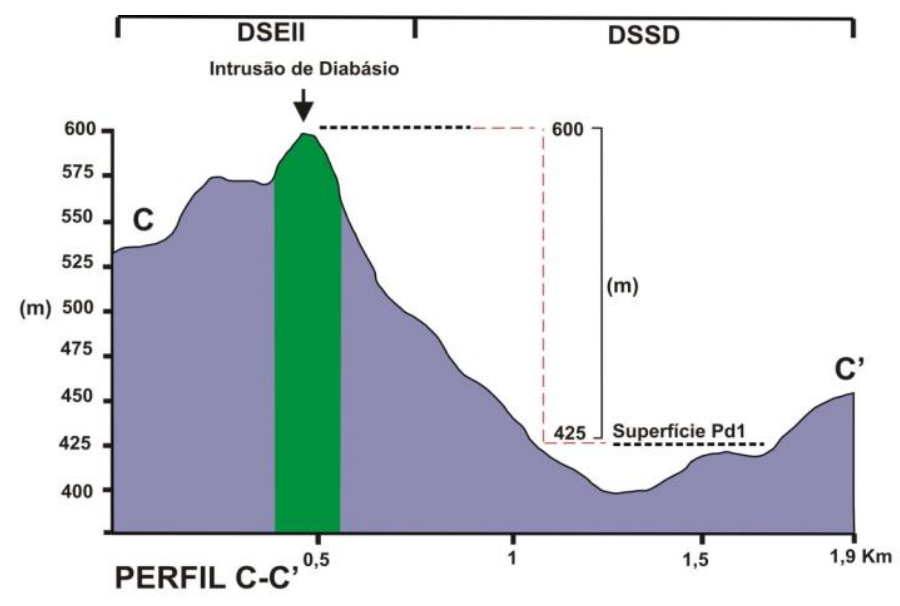

ESCALAS:

Escala vertical: $\quad \overbrace{25}$

Escala horizontal: $\underset{0}{0,5 \mathrm{Km}}$

Exagero vertical: $5 x$

GEOLOGIA:

Formação Rio do Rasto

Formação Serra Geral
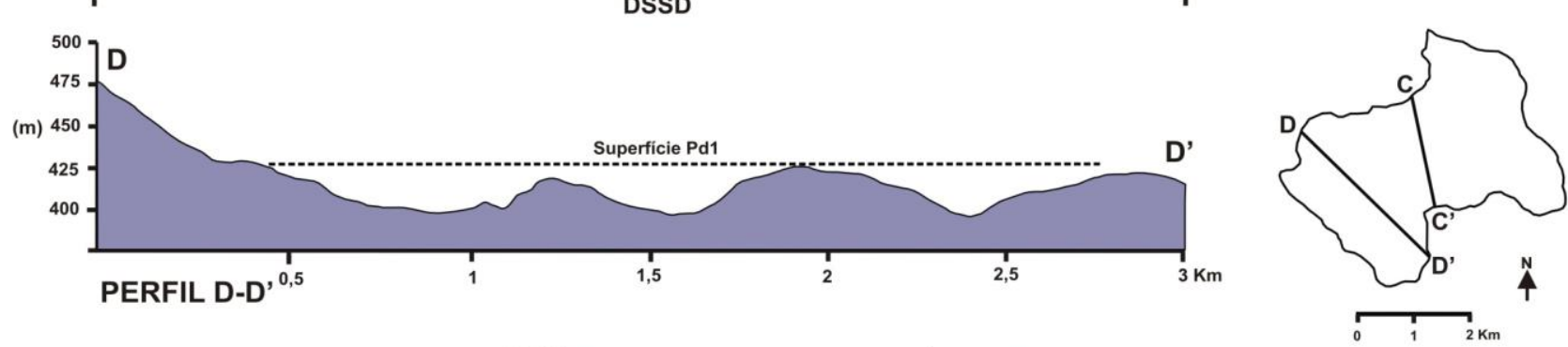

Perfis topográficos da bacia do Ribeirão Vovozinha

DSEII- Dominio das Superficies Estruturais Ígneas Intrusivas Perfis topográficos da bacia do Ribeir
ELABORAÇĀO: Eder Borges (2016)

Figura 14: Perfis topográficos da bacia hidrográfica do Ribeirão Vovozinha, Faxinal, cortes

C-C' e D-D'

\section{Conclusão}

Os produtos cartográficos, obtidos através dos trabalhos de gabinete (fotointerpretação de fotografias aéreas e geoprocessamento), aliados aos trabalhos de campo e à investigação teórica, representaram ferramentas importantes para a compreensão da morfodinâmica da área de estudo.

O domínio DSDE apresenta a maior complexidade fisiográfica da área de estudo, abarca feições expressivas de escarpas erosivas, escarpas adaptadas de falha, elevações residuais e ombreiras. Essas feições apresentam um prolongamento regional, atestado por estudos geomorfológicos realizados em bacias hidrográficas, adjacentes à área de estudo. As escarpas erosivas são estruturadas por rochas de idade mesozoica, porém as formas correspondem ao Paleógeno (65 m.a. - 23 m.a.) e Neógeno (23 m.a. - 1,8 m.a.) épocas em que ciclos erosivos atuaram no recuo dessas escarpas. Não raro, o recuo dessas escarpas abortou ao se deparar com estruturas resistentes, isolando feições de elevações residuais e diques. Atualmente, essas escarpas são submetidas ao processo de erosão remontante, por rios de primeira e segunda ordem.

Os domínios DSSI e DSSD apresentam feições de relevo similares entre si e distintas do domínio DSDE, o relevo monótono e colinoso, tem como base estrutural sedimentos paleozoicos, que se apresentam extremamente dissecados por uma rede de drenagem densa e recobertos por espessos depósitos quaternários.

O Ribeirão Vovozinha tem suas nascentes no domínio DSDE, próximo a feições escarpadas, típicas do contexto de transição entre o Terceiro e o Segundo Planaltos Paranaenses, o canal principal flui, predominantemente, na direção NE-SW. Na porção montante da bacia, a drenagem possui um nível de base local, representado por uma intrusão de diabásio, integrado ao domínio DSEII. A jusante, ao ultrapassar a zona de knick point, o canal adentra o domínio DSSD, onde é submetido ao nível de base do rio Pereira, até confluir no mesmo.

A geomorfologia é uma ciência complexa, que abarca uma infinidade de elementos de análise, a área escolhida para o presente estudo é caracterizada por uma heterogeneidade de elementos físicos. Embora as feições de relevo e a morfodinâmica apresentem similaridades e correspondência ao contexto regional, a morfogênese é também regida através de peculiaridades locais, influenciada pela atuação conjunta entre os elementos de drenagem e o fator estrutural.

A presença de feições de erosão acelerada apenas no domínio DSSD gera indícios de que os 
processos erosivos estão ocorrendo de forma concomitante e desigual entre as superfícies relativas aos domínios DSSD e DSSI, influenciados, conforme frisado anteriormente, pelo fator estrutural. Contudo, sob o ponto de vista da morfogênese, os vales de fundo chato, presentes no domínio DSSD, mais largos e recobertos por depósitos aluviais em zonas de planícies alveolares, são mais antigos que os vales em "V", presentes no domínio DSSI, considerados mais jovens. Todas essas constatações fornecem indícios de que os resultados obtidos, por este estudo, abrem precedentes para novas perspectivas de análise e novas pesquisas científicas, abordando a geomorfologia local.

A atual configuração altimétrica das super-

\section{Agradecimentos}

Meus sinceros agradecimentos ao professor Dr. Edison Fortes, por sua orientação, ajuda, suporte e conselhos, sem os quais a realização dessa pesquisa científica tornaria-se inviabilizada.

À professora Susana Volkmer, por orientações acerca da Geologia e suporte em campanhas de campo.

Ao GEMA (Grupo de Estudos Multidisciplinares do Ambiente), pela disponibilização do aparato estrutural (laboratório e sala de estudos).

À CAPES (Coordenação de Aperfeiçoamento de Pessoal de Nível Superior), pela bolsa de estudos concedida.

Aos colegas do curso de Pós-graduação em Geografia da Universidade Estadual de Maringá, dentre os quais gostaria de mencionar Karine Vargas (pelas conversas repletas de dicas e debates acerca de estudos geomorfológicos), Amália Teixeira e Thales Simões (pela prestativa ajuda em campanhas de campo).

\section{Referências}

Ab'saber, A. N. Compartimentação topográfica e domínios de sedimentação Pós-Cretáceos do Brasil. 1962. $80 \mathrm{f}$. Tese (Concurso para a cadeira de Geografia Física) - Departamento de Geografia, Universidade Federal do Paraná, Curitiba.

Ab'saber, A. N. 1969, Participação das superfícies aplainadas nas paisagens do nordeste brasileiro. Geomorfologia, São Paulo, 19, 1-38

Ab'saber, A. N. 1970, Províncias geológicas e domínios morfoclimáticos no Brasil. Geomorfologia, São Paulo, 18, 1-25.

Almeida, F. F. M. Origem e evolução da plataforma brasileira. Rio de Janeiro: DNPM/DGM, 1967. (Boletim, n. 241).

Bigarella, J. J.; Andrade, G. O. 1965, Contribution to the study of the Brazilian Quaternary. In: Wright Junior, H. E.; Frey, D. G. (Ed.) International studies fícies geomorfológicas, na região do Ribeirão Vovozinha, atestada pela curva hipsométrica dos perfis topográficos, demonstrados nas figuras 08,13 e 14 , está atrelada a um contexto evolutivo do relevo onde atuaram pelo menos dois ciclos morfogenéticos: um ocorrido no Plio-Pleistoceno (5,2 m.a. - 0,01 m.a.), em que climas áridos e semiáridos produziram a superfície de aplanamento Pd1, segundo autores já explanados (Bigarella et al., 1965; Bigarella e Andrade, 1965) e outro, correspondente ao Holoceno (0,01 m.a. - atual), úmido, onde a remodelação dessa superfície erosiva, por conta da rede de drenagem, ocorreu de forma diferencial, submetida ao controle estrutural exercido pelo dique de diabásio, de idade mesozoica.

on the quaternary. New York: Geol. Soc. Am. Spec, 433-451.

Bigarella, J. J.; Mousinho, M. R. 1965, Considerações a respeito dos terraços fluviais, rampas de colúvio e várzeas. Boletim Paranaense de Geografia, Curitiba, 16-17, 153-97.

Bigarella, J. J.; Mousinho, M. R.; Silva, J. X. 1965, Pediplanos, pedimentos e seus depósitos correlativos no Brasil. Boletim Paranaense de Geografia, Curitiba, 16-17, 117-151

DE Martonne, E. 1943, Problemas morfológicos do Brasil Tropical Atlântico. Revista Brasileira de Geografia, Rio de Janeiro, 4, 532-550. .

Fortes, E. et al. 2008, Controles morfoestruturais da compartimentação da serra geral: uma abordagem preliminar. Terra Plural, Ponta Grossa, 2, 279-292.

IBGE. Coordenação de Recursos Naturais e Estudos Ambientais. Manual técnico de geomorfologia. 2. ed. Rio de Janeiro, 2009.

Instituto de Terras, Cartografia e Geociências - ITCG. Dadosgeoespaciais de referência. Disponível em: $<$ http://www.itcg.pr.gov.br/modules/conteudo/conteudo.php?conteudo=105>. Acesso em: 26 mar. 2015.

King, L. A1956, geomorfologia do Brasil oriental. Revista Brasileira de Geografia, Rio de Janeiro, 2, 147265.

King, L. C.1953, Canons of landscape evolution. Bulletin of Geological Society of America, Washington, 7, 721-732

Maack, R. 1968, Geografia física do estado do Paraná. 3. ed. Curitiba: Imprensa Oficial, pp350.

Manieri, D. D. Comportamento morfoestrutural e dinâmica das formas do relevo da bacia hidrográfica do rio São Pedro Faxinal-PR. 2010. 89 f. Dissertação (Mestrado em Geografia) - Universidade Estadual de Maringá, Maringá.

Mineropar - Minerais do Paraná S. A. Atlas geológico do Paraná. Curitiba: Secretaria de Indústria, Comércio e do Turismo do Estado do Paraná, 2001. Disponível em: <http://www.mineropar.pr.gov.br/arquivos/File/MapasPDF/atlasgeo.pdf $>$. Acesso em: 26 mar. 2015. 
Santos, F. R. Condicionamento morfoestrutural do relevo e neotectônica da bacia hidrográfica do Bufadeira - Faxinal-PR. 2010. 46 f. Dissertação (Mestrado em Geografia) - Universidade Estadual de Maringá, Maringá.

Strugale, M. Arcabouço e evolução estratigráfica do Arco de Ponta Grossa no Grupo São Bento (Mesozoico): implicações na hidrodinâmica do sistema aquífero Guarani na migração de hidrocarbonetos na Bacia do Paraná. 169 f. 2002. Dissertação (Mestrado em Geologia Exploratória) - Programa de Pós-Graduação em Geologia, Universidade Federal do Paraná, Curitiba.

Strugale, M. et al. 2007.Structural framework and Mesozoic-Cenozoic evolution of Ponta Grossa Arch, Paraná basin, southern Brazil. Journal of South American Earth Sciences, Oxford, 24, 203-227.

Thomas, S. L. 1984, Sinopse sobre a geologia do Paraná. Boletim de Geografia, Maringá, 2.
Valeriano, M. M. Modelo digital de variáveis morfométricas com dados SRTM para o território nacional: projeto Topodata. In: Simpósio Brasileiro de Sensoriamento Remoto, 12. 2005, Goiânia. Anais... Goiânia: INPE, 3595- 3602. Disponível:

<http://marte.dpi.inpe.br/col/ltid.inpe.br/sbsr/2004/1 0.29.11.41/doc/3595.pdf>. Acesso em: 26 mar. 2015.

Vargas, K. B. et al. 2013, Evolução geomorfológica de feição dômica nas bordas planálticas do norte central paranaense. In: Simpósio Brasileira de Geografia Física Aplicada 15, Vitória. Anais.

Zalán, P. V. et al. 1990. Bacia do Paraná. In: Raja Gabiglia, G. P.; Milani, E. J. (Org.). Origem e evolução de bacias sedimentares. Rio de janeiro: Petrobras, 135-168. 